\title{
Banlieue Films Festival (BFF): Growing cinephilia and filmmaking in Senegal
}

\author{
Estrella Sendra \\ SOAS, University of London and Winchester School of Art, University of Southampton \\ es29@soas.ac.uk \\ http://orcid.org/0000-0001-8344-2928
}

\begin{abstract}
This article examines small film festivals in the socio-cultural context of Senegal. Through the case study of the Banlieue Films Festival (BFF) in Dakar, founded in 2013 by Abdel Aziz Boye, I analyse the crucial role of festivals in strengthening the film industry, fostering cinephilia and encouraging the practical application of cultural policies. I suggest that contemporary film production, particularly, in the past five years (2015-2020) has been significantly shaped by grassroots initiatives that have eventually been transformed into structures. I also explore the role of "rooted cosmopolitans", borrowing Kwame Appiah's term in relation to the figure of Abdel Aziz Boye, who founded Ciné UCAD at the Université Cheikh Anta Diop, in Dakar, Ciné Banlieue, and, upon returning to Senegal from France, the BFF. I discuss BFF's various forms of legacy, concluding that it has been an active agent in forging a new cinephilia and inspiring a wave of young filmmakers in Senegal.
\end{abstract}

KEYWORDS Banlieue Films Festival; Senegalese filmmaking; cinephilia; "rooted cosmopolitan"; film training; ethnography.

\section{Introduction}

Senegal enjoys an emblematic position in the history of African cinema. Following the increasing independence of African countries from French colonialism, Senegal became the home of pioneering filmmakers who would soon acquire international recognition, such as Ousmane Sembène (19232007), Safi Faye (n. 1943), and Djibril Diop Mambéty (1945-1998). These filmmakers sought to decolonise minds through the medium of film, and in doing so, to create a cinema from, by and for African people. In 1963, Ousmane Sembène became the director of one of the first fiction films made by a local filmmaker, Borom Sarret (1963), and of the first postcolonial feature-length Black African film, La Noire De... / Black Girl (1966), which earned him the title of "the father of African Cinema" among scholars and critics (Andrade-Watkins 1993, 29). In 2005, he was also the first African 
director ever to deliver the director's lesson at Cannes Film Festival, where he had been a jury member in 1967. In 1969, Senegal would also witness the first film production by Djibril Diop Mambéty, Contras' City / City of Contrasts, an experimental travelogue set in Dakar, which was a kind of "sketch-book" for his ground-breaking film Touki Bouki / Journey of the Hyena (1973), winner of the International Film Critics' Award at Cannes. Mambéty is considered one of the most paradoxical filmmakers in the history of African cinema, with a highly poetic and experimental style which placed marginalised people at the centre of the narrative (Ukadike 2002, 124). His impact is such that today there is a 'Mambéty-philia', a movement of filmmakers based in Paris and Dakar, including Franco-Senegalese filmmaker Alain Gomis (Diawara 2010). Another highly admired figure is Safi Faye, who directed the first feature-length film by a black African woman commercially distributed, Kaddu Beykat / Letter From the Village (1975), culminating in a prolific career which spanned over two decades. Safi Faye can be considered the mother of African cinema, with her work characterised for its focus on rural communities, oral history, spirituality and, very significantly, women. Her latest film, Mossane (1996), is considered "one of the most important films in the history and development of women's filmmaking in sub-Saharan Africa" (Bisschoff and Van de Peer $2020,140)$.

These pioneering Senegalese filmmakers offered a representation of "Africa through African lenses" for African audiences, which contrasted with the dominant "alien lenses" of hegemonic Eurocentric views, leading to "Tarzanistic" representations of Africa aimed at non-African viewers (Pfaff 1984, 1-10). Their focus on women, the marginal, and everyday life in a postcolonial society "struggling between tradition and modernity" (Diawara 2000, 84) are still recurrent themes within a country which continues to be at the epicentre of African film and screen media, despite the limited institutional support and increasing abandonment of cinema venues in the late 1970s (Krueger Enz, and Bryson 2018). In 2019, Mambéty's niece, Mati Diop, became the first black African woman to win an award at Cannes, with Atlantique / Atlantics (2019). In that same year, the fiftieth anniversary of FESPACO, one of the longest-running Pan-African film festivals, based in Ouagadougou, celebrated the talent of Senegalese filmmakers, such as women directors Angèle Diabang and Khadidiatou Sow. This festival had already honoured the work of another transnational Senegalese figure, Alain Gomis, winner of the Yennenga Golden Stallion twice, with Tey / Today (2012) and Félicité (2017). 
Today, the country boasts one of the few Africa-based cultural funds specifically devoted to supporting film production, the Fonds de Promotion de l'Industrie Cinématographique et Audiovisuelle/ Fund for the Promotion of the Cinematographic and Audiovisual Industry (FOPICA), established by the Senegalese government, in 2002. ${ }^{1}$ In this article, I suggest that the contemporary film production, particularly in the past five years (20152020), has been significantly shaped by grassroots initiatives. These have eventually been transformed into a structure and encouraged the implementation of FOPICA ever since 2014. I focus on a key grassroots initiative, the Banlieue ${ }^{2}$ Films Festival (BFF), founded in 2013 by Abdel Aziz Boye, and running on a biennial basis in the outskirts of Dakar. Abdel Aziz Boye is analysed here as an example of a "rooted cosmopolitan", a term borrowed from Kwame Appiah (2004, 213-273) to refer to individuals who identify as citizens of the world, due to different physical or psychological experiences of mobility. At the same time, they feel rooted in a particular place through diverse connections, such as birth, ancestry, love, friendship, or further symbolic experiences (Appiah 2005, 214). Such a sense of rootedness also prompts a feeling of active commitment with the roots, that is, of contributing to their transformation into better places, in order to give back (Appiah 2005, 241). Following over two decades in France, Abdel Aziz Boye returned to Senegal, where he founded Ciné UCAD at the Université Cheikh Anta Diop, in Dakar, and Ciné Banlieue, a film school which has created and hosted the BFF since its beginning. I look at the various legacies of this grassroots initiative by a rooted cosmopolitan, addressing the BFF as an active agent in forging a new cinephilia and wave of young filmmakers in Senegal, rooted in the socio-cultural context of Dakar and in the historic trajectory of the cinema produced since the early sixties. Ultimately, through the BFF case study, this article argues for the significant contribution of small film festivals to growing local film cultures and industries.

\footnotetext{
${ }^{1}$ The fund was created under Abdoulaye Wade's presidency. It offers financial support to film and screen media projects shot in Senegal or by Senegalese filmmakers. FOPICA, however, did not start functioning until 2014, under Macky Sall's government. By then, film festivals in Senegal had already been running for years.

${ }^{2}$ This is the French word for "outskirts" and the suburban area.
} 


\section{Research methods}

This article is informed by both my research and practice. During my doctoral research, I conducted fieldwork from October 2015 to September 2016 in different regions of Senegal. During this time, I interviewed festival organisers and other cultural actors, accessed a wide range of oral and written archives about festivals in Senegal, and read books written by Senegalese scholars that are difficult to access elsewhere, while also establishing connections with some of them. I relied on what I then identified as immersive ethnographic methods, notably, participant observation. Immersive methodologies emphasise collaboration and participation, with a willingness to give back. This was inspired by Hélène Neveu Kringelbach's methods and reflection on the "distrustful [local perception] of the ethics of research in Africa by outsiders" who draw conclusions after a period of observation and "go back to be called an 'expert'” $(2013,24)$.

This awareness translated into various forms of participation in and collaboration with the festival scene, such as sharing photographs and videos with research participants, co-authoring a conference paper and journal article with a Senegalese scholar, and presenting my thesis in three different urban and rural locations in Senegal. ${ }^{3}$ My access and immersion in (part) of the festival scene as a researcher from SOAS, University of London, was also shaped by my previous practical media experience in the country, interning as a cultural journalist at Le Soleil in the summer of 2012; and as a Spanish white filmmaker based in Senegal who had screened a documentary about migration from Senegal to Spain. ${ }^{4}$ Linguistic skills were key in this immersive ethnography. I was fortunate to be awarded the SOAS Language Acquisition Fund to learn Wolof ${ }^{5}$ prior to conducting fieldwork. While still not at a native proficiency level, I was able to understand the vast majority of oral conversations, since this remains the preferred language, particularly when sponsors and institutions are not present. Being able to

\footnotetext{
${ }^{3}$ A hard copy of the thesis is now available at the FESFOP archives, in Louga, and a digital one can be found in Aula Cervantes, in Dakar. FESFOP is the non-profit organisation responsible for organising the International Festival of Folklore and Percussion, in Louga.

4 The success of this film screening inspired a follow-up documentary, which I co-directed with Senegalese communication expert, Mariama Badji, the protagonist of the first film. This was shot and screened in Senegal with a Senegalese crew composed of Nazir Cissé as the cameraman and Mamadou Khouma Gueye as sound engineer, two young filmmakers trained by Abdel Aziz Boye in Ciné Banlieue.

5 Wolof is the main national language and lingua franca. A legacy of colonialism, French remains the official language, despite the limited percentage of fluent French speakers, particularly beyond Dakar and Saint-Louis, former colonial capitals.
} 
understand Wolof was indispensable to interact with people, as well as to follow presentations and discussions during festivals. I was able to identify the difference in content when switching from French to Wolof, depending on the target audience at the festivals (sponsors, filmmakers, neighbours, etc.). Most interviews in Dakar were conducted in French, at times shifting from French to Wolof or vice-versa, or as part of a multilingual repertoire, which is the norm in oral conversations in Senegal. Some interviews or conversations were also conducted in Spanish, due to the involvement of Cultura Dakar, the cultural section of the Spanish Embassy in Dakar, in the 2015 festival, and the linguistic skills of some research participants.

BFF was one of the 17 festivals I observed and participated in from October 2015 to September 2016, but my relationship with this crucial space of growth in cinephilia and training of young filmmakers dated back to 2012, when I first met Mamadou Khouma Gueye and Nazir Cissé. In 2013, when I was working in the international media office of the African Film Festival of Cordoba-FCAT (now based in Tarifa and Tanger), three young Senegalese film and screen media professionals won grants to participate in a film criticism workshop led by Federico Olivieri and taught by Olivier Barlet. Two of these were Pape Bolé Thiaw and Keba Danso, also attached to Ciné Banlieue. Following our festival encounter, they invited me to screen my documentary at Ciné Banlieue and give a talk to young, aspiring filmmakers. Their professor was Abdel Aziz Boye. This first screening was followed by another two, in subsequent years, the last one being in 2019. ${ }^{6}$ This continuous engagement with Ciné Banlieue, which included interviews ${ }^{7}$ and conversations with its members, as well as digital ethnography of their festival and other activities, has culminated in this journal article. Through it, I hope to vindicate the crucial role of Abdel Aziz Boye and Ciné Banlieue in the context of growing cinephilia and filmmaking in Senegal. So far, BFF has not received any scholarly attention. In fact, there is still scarce work on film festivals in Senegal, arguably due to their 'small' size and young trajectories. While aware of these features, I wish to highlight the emblematic role that a small non-hegemonic film festival like BFF can have in the cultural realm of Senegal and, indeed, the impact of this kind of event in any other such place around the world.

\footnotetext{
${ }^{6} \mathrm{Mr}$ Boye passed away on 9 November 2017. As a journalist, I paid tribute to him by publishing two obituaries, in the Spanish online magazine, Wiriko, and in the Senegalese newspaper Le Soleil.

${ }^{7}$ These were done mainly in French, with some Wolof moments. Federico Olivieri's interview was done in Spanish. The statements I quote here are my free translations into English.
} 


\section{Small film festivals in Senegal}

Film festivals are "multisensory, multifocal" events (Kirshenblatt-Gimblett 1998, 57), which vary in size, shape, theme and approach. In Marijke de Valck's words, “[t]hey offer a unique combination of corporeal, visceral, and mental stimulation, engaging multiple senses, offering intellectual stimuli, and allowing social connection" $(2016,9)$. This author also notes that "fixed definitions do little to advance our understanding of film festivals" (2016, 1). Instead, de Valck suggests, we need theoretical frameworks, able to elucidate the facets that generate different forms of festive excitement. In this article, I build on the film festival scholarship that has emphasized the emblematic role played by festivals in film culture (de Valck 2007, Iordanova 2016, Loist 2016, among others). I draw on Janet Harbord's understanding of festivals as structures resulting from the cyclical periodicity of the festival event (Harbord 2016, 70) to emphasise the longterm importance of film festivals, as structures and spaces that foster cinephilia and filmmaking beyond the live event. This is particularly important in the context of non-hegemonic languages, cultures and film festivals. As Senegalese filmmaker Moussa Sene Absa argues, "without festivals, African cinema wouldn't exist" (cit. in Dovey 2015, 3), which resonates with de Valck's argument that festivals have become so important that, "without them, an entire network of practices, places, people, etc. would fall apart" $(2007,36)$. De Valck also describes film festivals as crucial "sites of passage that function as the gateways to cultural legitimization" $(2007,38)$. As films travel along the festival circuit, they accumulate value, through prizes, and reviews, thus becoming more attractive to further festivals, and more eligible to continue travelling across the international festival circuit (de Valck 2007, 35).

However, the film festival circuit constitutes a hierarchical network and hegemonic account of film culture and film history (Loist 2016). The value added to films depends on the size of the festival in which the film is showcased, as well as on the festival position within the international film circuit (de Valck and Soeteman 2010, 294). Lindiwe Dovey, pioneer in the inclusion of Africa in film festival theory, argues that there is a "narrative of exclusion" of African cinema at film festivals $(2015,50)$. This is reflected in film scholarship, with exceptions (see Fléchet 2013; Mano, Knorpp and Agina 2017). Dovey notes how, in prestigious international film festivals like Cannes, Africa has been absent, or as Cindy Hing-Yuk Wong suggests, "a blatant area of neglect" $(2011,61$, cit. in Dovey 2015, 48). This narrative of exclusion, Dovey argues, "touches on the broader, international perception 
of Africa, African films, and African filmmakers, as well as the specific relationships among a whole swathe of French institutions and former French colonies in Africa" $(2015,50)$. A focus on film festivals in Senegal, then, allows for an examination into the forms of contesting hierarchies within international film festivals.

Film festivals in Senegal are still recent phenomena when compared to other cultural festivals which have proliferated significantly across the whole country since the year 2000. With a few exceptions, most of the film festivals celebrated to date started after 2010. Whilst in this article I specifically focus on the BFF, in this section I briefly introduce other Senegalese film festivals in order to frame and study BFF as part of a larger festival network. In so doing, I seek to establish some basis for future research on the broader film festival network in Senegal, and further indepth studies on specific festivals within the country and their role in Senegalese and international film culture. These festivals include, in chronological order, the Rencontres Cinématographiques de DakarRECIDAK (1990), Festival Image et Vie (2001), Festival Films Femmes Afrique (2003), Festival Itinérant de Cinéma en Plein Air-AFRIKABOK (2009), Banlieue Films Festival (2013), Festival International du Film Documentaire (2014), Festival de Ciné Droit Libre (2014), Festival Gorée Cinema (2015), and the Festival International du Court Métrage-Dakar Court (2018).

The first festival exclusively dedicated to showcasing film can be considered the Rencontres Cinématographiques de Dakar-RECIDAK, despite the fact that it does not include the word "festival" in its name. Established in 1990, it was initially conceptualised as a private initiative, but it was then managed and funded by the state, becoming the only government-run film festival in Senegal, overseen by the Ministry of Culture and Communication. In line with further state-organised cultural festivals, the organisation and management of this film festival has been challenging, which is reflected in its interrupted periodicity. From 1990 to 1996, the festival took place on an annual basis. After this date, there was no festival until 2018 (Le Quotidien 2018). The first non-state film festival initiative was Festival Image et Vie. Founded in 2001, it aimed to showcase cinema across the country, in response to the limited film infrastructure in Senegal in the 1990s that was marked by the abandonment and closure of film exhibition venues, but with an eager youth willing to make films for circulation in the international film festival circuit (Africultures n.d.). With an international programme that devotes a special place to African cinema, the festival is organised 
thematically, with debates and panels on the annual theme. The screenings are hosted in film venues and open-air pop-up cinemas set up temporarily for the festival. Over time, Festival Image et Vie has received increased institutional support, and established partnerships with further international film festivals. In 2009, Festival Itinérant de Cinéma en Plein Air-AFRIKABOK appeared as the first itinerant film festival in Senegal, with different and multiple festival locations per year. It is one of the rare festivals directed by a non-Senegalese cultural actor based in the country, Bruno Ventura. The festival receives regular periodical celebration and is also an illustrative example of the interdisciplinarity of cultural festivals in the country. This is a recurrent creative curatorial technique in Senegalese festivals. When they are not music festivals, which enjoy a high degree of popularity, they often include different art forms, notably, music, in their programmes, aiming to make it more appealing to wider audiences. The programme of AFRIKABOK does not just include film screenings, but also music, particularly dance and performances by griots ${ }^{8}$ and local groups framed by the festival as "traditional."

A couple of years later, in 2003, a film festival exclusively devoted to women, Festival Films Femmes Afrique (African Women Film Festival) was launched. However, following its launch, the festival disappeared for twelve years. Interrupted and irregular periodicity is a common feature in the festival scene in Senegal, due to the limited financial state support and the consequent reliance on the generosity of individual initiatives from cultural actors who want to contribute to enhancing the cultural profile of their local regions. The uncertainty and challenge of sustainability are often further complicated by a dependence on institutional support from cultural attachments of foreign ministries based in the country, such as Institut Français (France), Goethe Institut (Germany) and Aula Cervantes (Spain), and non-governmental organisations. Ever since its reappearance in 2016, the festival has been hosted biennially, gathering over 9,000 spectators over multiple venues spread across different regions, which, in 2020, included: Fatick, Kaffrine, Kaolack, Louga, Rufisque, Saint-Louis, Thiès and Ziguinchor. Film screenings are free, and the programme includes various competitive and non-competitive sections, as well as a focus on Senegal.

Since 2010, a number of other film festivals have been launched in the country. One such festival was the BFF. Starting life as a small film festival

${ }^{8}$ These are storytellers and masters of the spoken word of historical importance. 
to showcase the work of young filmmakers during their training at Ciné Banlieue, the festival has grown to include the most internationally acclaimed Senegalese filmmakers and even on occasion, film productions from different African countries. The Festival International du Film Documentaire (International Festival of Documentary Film) has been running annually in Saint-Louis since its creation in 2014. Its origins can be traced back to 2002, when a first writing residency took place in Gorée Island. This was followed by further meetings in 2003, which led to the creation of the Africadoc programme, involving a series of African countries, and is concerned with documentary film production. Following the co-production meetings organised in Saint-Louis since 2006, a programme of film screenings followed by debates was established in 2010 . The emphasis on internationalisation led to the creation of a dedicated association, Docmonde, aiming to contribute to the creation of an international network of independent directors and producers. The initial film screening programme would, in 2014, be transformed into an annual international documentary film festival and has since been consistently hosted on the island of Saint-Louis (docmonde n.d.). During the festival, the city, and increasingly more spaces within the region of Saint-Louis, become open-air cinemas with images projected onto pop-up screens or street walls, imbued with a festival spirit through curated talks with filmmakers. Today, the festival counts on the support of multiple organisations, mainly institutions, such as the Organisation international de la Francophonie (OIF), the Institut Français, the town hall, the Cinematography Department and TV5 Monde (au Sénégal 2020).

In 2014, Senegal was also home to its first human rights film festival Festival Ciné Droit Libre - hosted annually in four different African countries: Senegal, Burkina Faso, Mali and the Ivory Coast. It offers a platform for the showcasing of films that have struggled to achieve distribution or been censored in their own countries of production. The festival also considers different screen media, with the selection of one television series from across the world with a particular focus on Africa. The festival centres on the right to freedom of expression, but also promotes other human rights through the moving image. One year later, Gorée Island became home to the Festival Gorée Cinema, also hosted annually since 2015, and programmed around cycles of cinema across time periods, which has been running during the summer since its second edition. Its main screening venue is an open-air pop-up screen by the pier where boats arrive or depart from and to Dakar. The festival also includes a forum space, named Diisoo Cinéma, an intimate space hosted in a small gallery near the 
Maison Gorée Island Cinema, where festival organisers and guests are based. Whilst open to the public, it is mainly targeted at journalists and a few cinephiles, who comprise the whole limited audience. It also hosts panel discussion with guest filmmakers, who are also present after the film screening by the beach, for a Q\&A with the audience. The latest addition to this Senegalese film festival circuit is the Festival International du Court Métrage-Dakar Court, the first African film festival dedicated exclusively to short fiction films. This was founded in 2018 by the Cinemarekk Association, led by Moly Kane, a young cinephile attached to Ciné Banlieue, who also directed Muruna (2015), a film screened in the second edition of the Banlieue Films Festival, in 2015, raising awareness of sexual harassment of women. While still very young, this festival enjoys a central position in the promotion of emerging African filmmakers. Its second edition received over 200 submissions, which took shape in a carefully curated programme, which included a retrospective of pioneering African films, such as Et la Neige n'Était Plus (Ababacar Samb Makharam, 1965, Senegal), winner of the Best Short Film Award in the First World Festival of Negro Arts, hosted in 1966, in Dakar, and the participation of acclaimed filmmakers and critics, such as Mati Diop, who delivered a masterclass. Whilst relatively "small" in their size, these festivals play a crucial role in the contemporary film culture of Senegal. 
The role of rooted cosmopolitanism in growing cinephilia and filmmaking: Abdel Aziz Boye

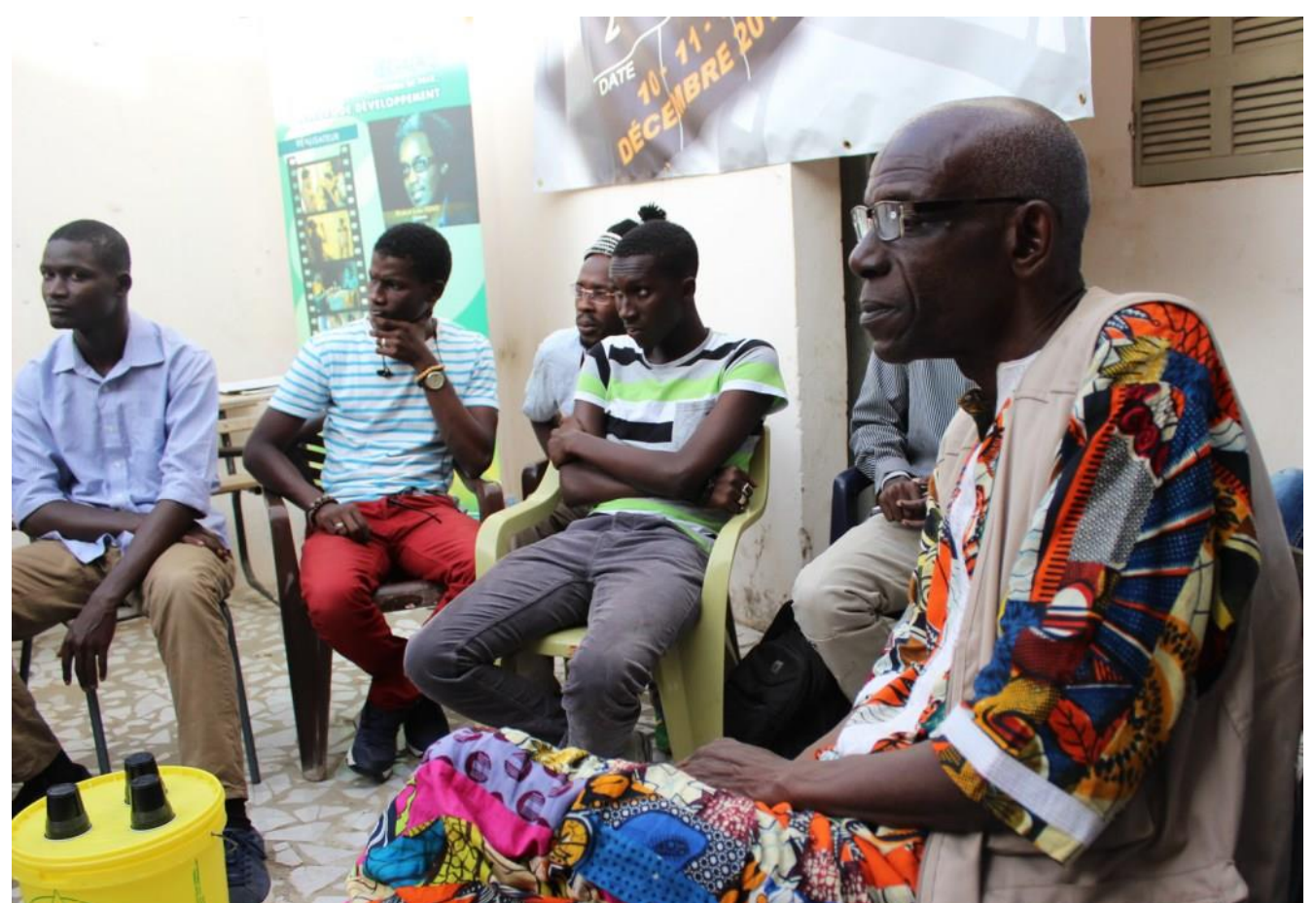

Image 1: Abdel Aziz Boye (right) surrounded by his students, in a masterclass during the 2nd Banlieue Films Festival | Photo by Estrella Sendra (12/12/2015).

Abdel Aziz Boye was born in 1953 in Saint-Louis, Senegal, where he lived near the then Vox cinema. His relationship with cinema started at a very early age. He used to tell how, at the age of seven, he would create his first moving images, with cardboard, and that ever since film was always part of his life. He introduced himself as "a crazy cinephile" (Sendra 2017a). Following his studies in the school currently called Émile Sarr, Abdel Aziz Boye went to France to pursue his film studies at the Free Conservatory of French Cinema. He continued his higher education in the University Paris VIII, in the department of psychology and sociology, a period in which he continued to forge his filmmaking career, collaborating with different filmmakers. In 1992, he became the assistant director of Ousmane William Mbaye's film Fresque Francophone, and worked in another film, entitled Talatay Nder, which would not be finished. It was during the shooting of this film that Abdel Aziz Boye returned to Senegal, where he ended up staying, in order to share his experiences with young cinephiles and aspiring filmmakers (Sendra 2017b). This was 22 years after his departure to Paris, and would be followed by the set-up of Ciné UCAD, and of Ciné Banlieue, in 
2008, for free film training aimed at young people coming from the outskirts of Dakar.

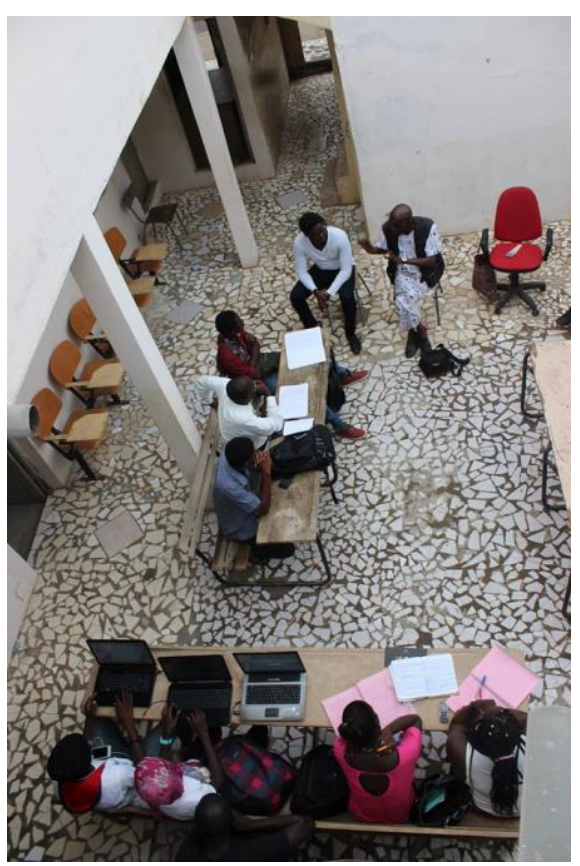

Image 2: Abdel Aziz Boye training young filmmakers at the Cine Banlieue School Photo by Estrella Sendra (24/07/2016).
Abdel Aziz Boye encompasses the important role that "rooted cosmopolitans" have had in the festivalisation of Senegal. By founding these film training spaces with two different target groups, he was giving back (Appiah 2005, 241), contributing to film culture in Senegal, playing tribute to its determining historic role by teaching Senegalese people about Senegalese filmmakers, and by providing practical tools for filmmaking. He became a mentor for many young Senegalese filmmakers, both men and women, who would use the film medium to denounce the realities of the socio-cultural spaces they inhabited. The first Ciné Banlieue was located in the socio-cultural centre of Guédiawaye, gathering young people

living also in neighbouring areas, such as Guinaw-Rails and Keur Massar. These origins led to the production of short films such as Guinaw Rails / Behind the Rails (Kady Diedhiou, 2014), concerned with the social living conditions in the outskirts of Dakar, where much of the Senegalese population had been displaced during the French colonial period. After one year in Guédiawaye, Ciné Banlieue moved to the Léopold Sédar Senghor Cultural Centre in Pikine, also in the outskirts of Dakar, to then find its own space nearby, in the area of Parcelles Assainies. Boye's passion for cinema and generosity led to the transformation of the house into a school, with classrooms named after leading figures of Senegalese cinema, such as Djibril Diop Mambéty and Ousmane Sembène. Open for over a decade now, Ciné Banlieue is the only space allowing young people in the outskirts to freely access film training on an ongoing basis, at the weekend. As Pape Bolé Thiaw puts it, "the students in Ciné Banlieue are cinephiles. Their only condition to join is to be passionate for cinema and to want to make films" (personal communication, 2015). It has also become a reference for film culture in Senegal. Filmmakers are aware of this space, having often engaged with it by delivering workshops, and thus contributing to its practice-based teaching approach. 
Abdel Aziz Boye, known by his students as Mr Boye, is also what Amanda Davies calls a "transformational leader" (2011). These are inspirational, charismatic leaders who appeal to self-interested followers, who want to join the network because of their admiration for the leader (Davies 2011, 61). The interest relies then on the "social capital" (Bourdieu 1986) of the project, rather than on its economic capital. Like in other festivals worldwide (see for instance the work by Quinn and Wilks 2016), social capital is key in the festivalisation of Senegal, since these are mainly led by individual initiatives, from artists and cultural actors, eager to contribute to the local transformation of their communities. Such social capital is largely due to the admiration young cinephiles feel towards such generous individuals. Pape Bolé Thiaw, one of the filmmakers trained at Ciné Banlieue, and later the coordinator of the festival, described Abdel Aziz Boye as "a mentor, an educator, but above all, a father" (personal communication, 2017). Similarly, his peer, Keba Danso, talked about him as "a person who loved cinema and gave us all his time, helping us without asking for anything in return", adding: "this person saved the lives of many young people from the outskirts, making us believe in ourselves and reassuring us that we can be the tellers of our own stories" (personal communication, 2017). Lamenting his death, Nazir Cissé, a former student from Ciné Banlieue working as a professional camera-man and editor for LEVEL studio, stated: "he was the one who made me love cinema... Everything I know about filmmaking is through him. I am not the only one. He has educated many young cinephiles from the outskirts, and has done it for free. He is a big one in Senegalese culture" (personal communication, 2017). Boye is, indeed, a key figure in the history of Senegalese cinema, crucial for our understanding of the role film festivals can play in the rethinking and redesigning of the industry from a grassroots, practicebased perspective. 


\section{Banlieue Films Festival as a structure}

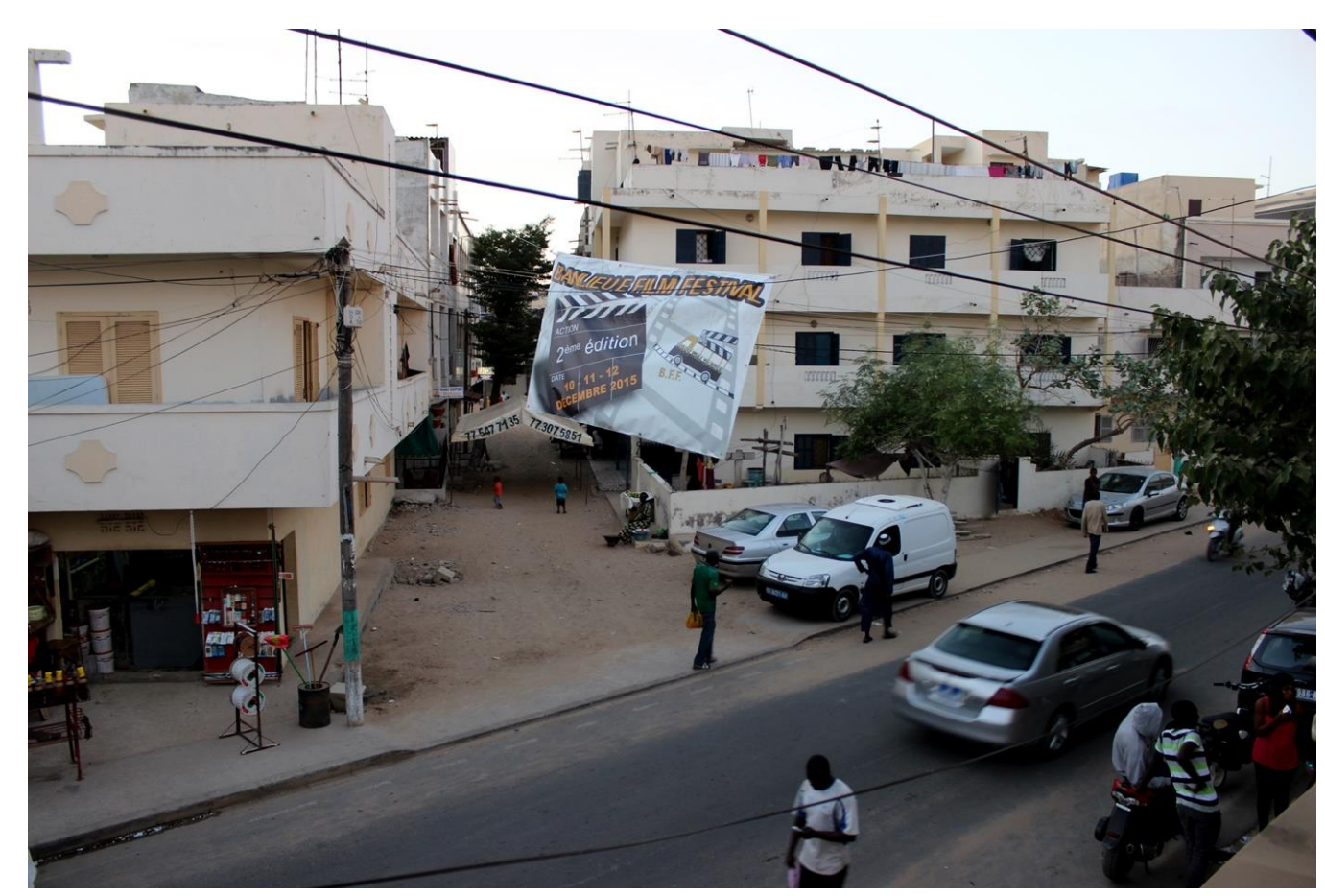

Image 3: View of Parcelles Assainies in Dakar, from the terrace of Ciné Banlieue during the 2nd Banlieue Films Festival | Photo by Estrella Sendra (12/12/15).

BFF runs for three days, hosting film screenings on the attic, against the wall, faced by rows of colourful plastic chairs, in the intimate darkness of the night. It also hosts day-time workshops with speakers from the Senegalese film and screen media industry. The festival audience is mainly composed of the young filmmakers from Ciné UCAD and Ciné Banlieue, as well as cinephiles from the outskirts. It was born as a platform to showcase the work made by students in Ciné Banlieue, on a very small and low-cost format. Its initial curatorial approach essentially consisted of showcasing the works completed during the film training at Ciné Banlieue, with the aim of inserting them into the broader festival circuit, thus taking on the role of gate-keeper. Its second edition, in 2015, opened with Linguère, a 26-minute film made collectively by Ciné Banlieue members, such as Momar Talla Kandji, who to this day, continues his career as a filmmaker and trainer in Ciné Banlieue. His first short film, Ordur / Trash (2018) won awards in the Panafrican Festival of Cinema and Television (FESPACO) and has screened in over 12 film festivals in Africa and Europe, such as the Festival Gorée Cinema and the African Film Festival in Barcelona (FICAB). The film is highly representative of the recurrent themes emerging from Ciné Banlieue, 
which, like the films by much-admired Mambéty, place the marginal at the very centre of the narrative. They focus on everyday forms of struggle, which seem subtle but are highly illustrative of the resilience in a society characterised by contrasts left by colonialism. Further recurrent themes are religion, spirituality, beliefs and local traditions, as can be seen in titles such as Baye Fall, Le Soldat de la Paix/ Baye Fall, Peace Soldiers (Pape Bole Thiaw, 2015), screened in the second edition, or Niaka (Baba Diedhou, 2019), shown in the fourth edition, which sheds light on a cultural practice by women from Lower-Casamance, in the south of Senegal.

Within this short trajectory, the festival's evident social and cultural capital has spurred its expansion. In 2015, the festival collaborated with the Slum Film Festival, ${ }^{9}$ in Kenya, thus engaging with a collaborative and reciprocal curatorial practice that showcased Kenyan titles made in the slums in exchange for Senegalese titles made in the outskirts of Dakar. This collaboration was also the outcome of social capital recognition and of international experiences. In 2013, Pape Bolé Thiaw was one of the students sponsored by AECID 10 to attend the film criticism workshop at the $10^{\text {th }}$ African Film Festival of Cordoba-FCAT. The workshop, taught by Olivier Barlet, was led by Federico Olivieri, co-founding director of the Slum Film Festival in Kenya. Social capital transformed then into cultural and economic capital, since BFF received funding from Cultura Dakar, the cultural attachment of the Spanish embassy in Dakar, which also contributed to the internationalisation of the festival.

BFF's growth has been even more significant within Senegal itself. Firstly, it has diversified its exhibition spaces, moving from Ciné Banlieue to places such as the exhibition site 'Complexe Ousmane Sembène', in its fourth edition, which enabled the festival to reach wider audiences. Secondly, it has witnessed an increasing involvement by leading Senegalese filmmakers, with the selection of a patron per year, such as Alain Gomis, in 2017, and Safi Faye, in 2019. From its second edition, the BFF programme also included film screenings by renowned, award-winning Senegalese filmmakers, such as Une Simple Parole/ A Simple Word (Khady and Mariama Sylla, 2014), which features the personal journey of two sisters (the directors) to their grandmother's rural village. In 2019, it screened Mossane

${ }^{9}$ For a study of this festival, see Dovey, McNamara, and Olivieri (2013).

${ }^{10}$ This is the Agencia Española de Cooperación International para el Desarrollo (Spanish Agency for the International Cooperation for Development), which depends on the Ministry of Foreign Affairs, and the European Union. 
(Safi Faye, 1996), which intertwines personal themes like mother-daughter relationships, women's sexuality and friendship with issues like migration, spirituality and rural lifestyles. These screenings, followed by debates, celebrated the talent of Senegalese filmmakers while showcasing films that drew upon and raised awareness of socio-cultural issues - often emerging from the lived experiences of their filmmakers - that concern the Senegalese population. These involvements and curatorial approaches contributed to the cultural legitimisation of BBF as a meeting point for cinema. Thirdly, BFF has successfully established connections with multiple film festivals in the country, feeding their programmes overwhelmingly with films made by Ciné Banlieue members. Former students of Ciné Banlieue went on to create other festivals - like Moly Kane, founder of the Dakar Court. Another key name from Ciné Banlieue is Amath Ndiaye, still attached to Ciné Banlieue as a teacher. Interested in animation, he was first taught by Boye in 2008. His first short film, Gueti Goudi (2012), employed innovative film language (no dialogue, an exquisite colour treatment and photography, and a remarkable sound design), which brought it to the attention of film festivals like the Festival Gorée Cinema. Following this success, Ndiaye's dream to make an animation film was fulfilled with Ganja (2019), which became the first Senegalese animation film in Wolof (Drame 2019), winning that year's award for the Best Senegalese Short Film in Festival Image et Vie.

Festivals are "public events that invite us to position ourselves in the midst of other bodies - of curators, spectators, jury members, filmmakers introducing, watching, laughing at, commenting on, judging, rejecting, and discussing those films" (Dovey 2015, 22, my emphasis). This social dimension is a crucial characteristic in a small film festival like BFF. It does not only give visibility to filmmakers, but it also operates as a networking space, forging opportunities of mobility for both films and filmmakers showcased at the festival. 


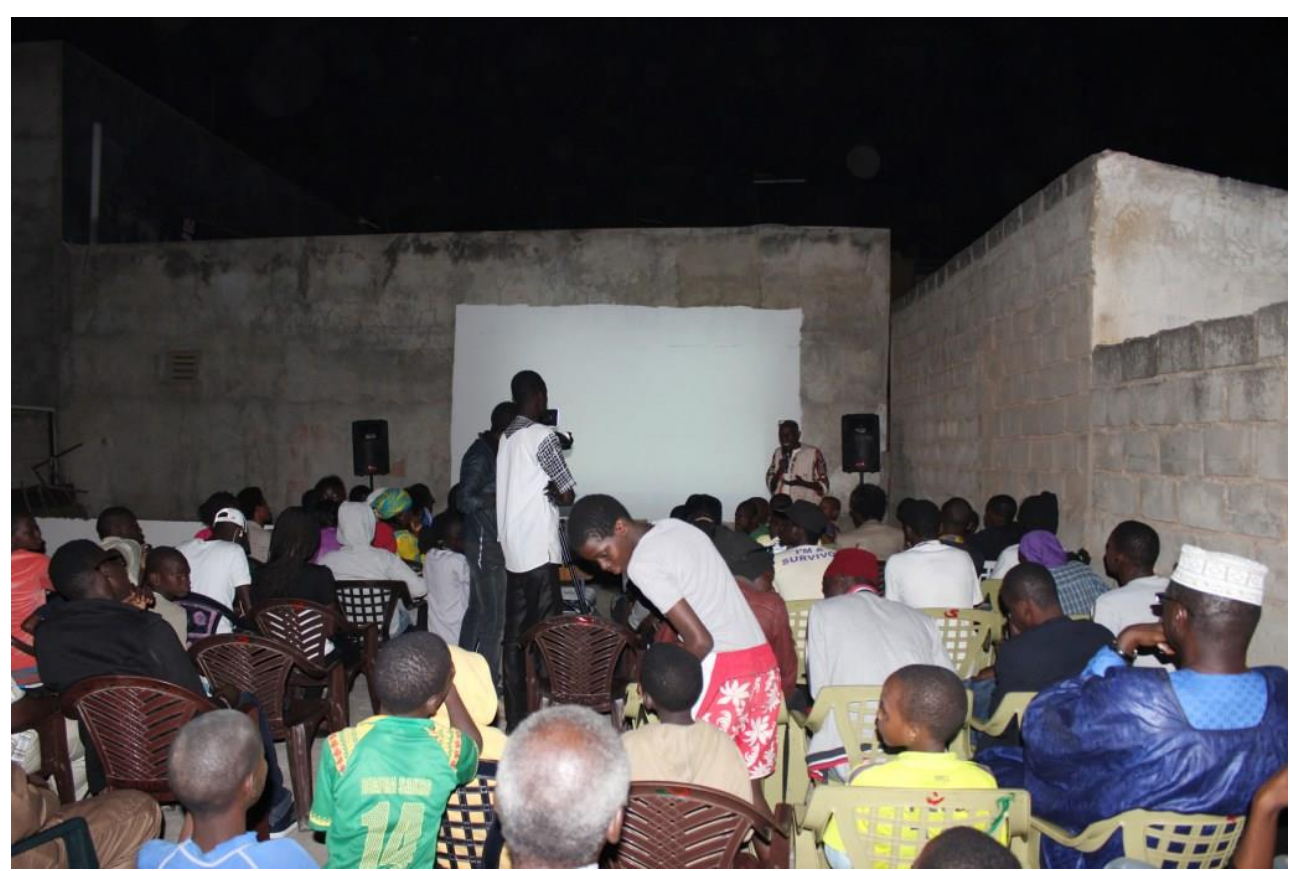

Image 4: Abdel Aziz Boye welcoming audiences in the 2nd Banlieue Films Festival | Photo by Estrella Sendra $(12 / 12 / 15)$.

What starts as a small film festival then becomes a structure due to their cyclical characteristics, as Janet Harbord notes $(2016,70)$, and further connections are built year-round. When the festival is over, the structure continues, cyclically reappearing, making the films for the following edition and providing films to further Senegalese festivals.

\section{Pour que la flamme engendré ne s'éteigne jamais 11: the legacy of Ciné Banlieue}

When Abdel Aziz Boye passed away, social media became a healing public sphere where people shared condolences, memories and praises of a key figure in Senegalese cinema. Rama Thiaw, director of the award-winning documentary film The Revolution won't be Televised (2016), would write: "I am really sad. With great generosity and very limited means, this man has done so much for Senegalese cinema and the training of young people from the outskirts and popular neighbourhoods. Rest in peace. A great man!" (cit. in Sendra 2017a). Today, as Ciné Banlieue members keep making films and

${ }^{11}$ Let us prevent this flame from extinguishing. 
hosting the festival, a recurrent phrase is present in the communication of the event: Pour que la flamme engendré ne s'éteigne jamais, evidencing a sense of responsibility and paying tribute to Boye, by making his project grow. Abdel Aziz Boye lives still through his legacy (Dakar Ciné, 2019). He was a firm advocate of Senegalese cinema, insisting that it survives despite the disappearance and closure of a large number of cinema venues (Sendra 2017a). The contemporary scene proves his efforts have not been in vain. Festivals are "not mere barometers of changing norms, but forces that drive, shape and legitimise change" (de Valck and Soeteman 2010, 290-294).

Ciné Banlieue, led by Abdel Aziz Boye, has highly contributed to the practical implementation of the various aims of the Direction de la Cinématographie (DCI), as well as the FOPICA. ${ }^{12}$ It has become a space of reference, a meeting point and networking space to build a community of cinephiles and filmmakers in the country. This makes it an ideal place for the communication of the various initiatives, from the DCI to FOPICA. For example, during training on Saturdays with Abdel Aziz Boye, flyers of FOPICA would be on the tables, and referred to explicitly by Mr Boye. Ciné Banlieue continues to run in Parcelles Assainies, now in two different locations, the original one, in number 24 , and another one, in number 17 , where young filmmakers continue to organise the training of fellow cinephiles and aspiring filmmakers. Some have already left, to make space to the next generation. Today, Ciné Banlieue alumni are finding their place in the national and international film festival circuit: Amath Ndiaye, Khebara Traoré, Khadidiatou Sow, Momar Talla Kandji, Pape Bolé Thiaw, Mamadou Khoma Gueye, Armando Lo, Mamadou Socrate Diop, to name but a few. Within the international film circuit, they have also had international experiences in film training. These platforms for film and filmmakers are largely shaped by networking opportunities, as is the case with membership in Ciné Banlieue and participation in the BFF. Ciné Banlieue has generated a crucial "cultural capital" grounded on a strong basis of "social capital" (Bourdieu 1986) led by the rooted cosmopolitan Abdel Aziz Boye. For instance, Pape Bolé Thiaw, former festival manager of the Banlieue Films Festival, was awarded a scholarship to study film at the prestigious FEMIS (École Nationale Supérieure des Métieres de L'image et du Son), in France, which led to the making of his 13-minute short film Daani

\footnotetext{
${ }^{12}$ On 9 November 2000, the Ministry of Culture and Communication created this unit, specifically devoted to Cinema. The DCI, officially translated as 'the Cinematography Department' was established by decree in order to "ensure, under the authority of the Minister of Culture, the unity of design and implementation of the policy of the Senegalese State in the fields of cinema and audiovisual" (Sencinema, n.d.).
} 
Doolé/ Self-autonomy (2017). In acknowledgement of his training, Bolé Thiaw reserved the world première for Ciné Banlieue (personal communication, 2015). The film followed the aforementioned short film Baye Fall, Peace Soldiers (2015), which also enjoyed some circulation in the international film circuit. His colleague Khadidiatou Sow further witnessed the circulation of her sixteen-minute short film Une Place Dans l'Avion / A Seat on the Plane (2016), awarded in FESPACO 2019. Nazir Cissé is now a well-established cameraman and editor of music videos with LEVEL studio. These are just some of the names of the wide range of filmmakers who have emerged from Ciné Banlieue, whose productions are often dedicated to Abdel Aziz Boye and include him in the acknowledgments.

In order to examine such socio-cultural legacy, it is now important to analyse the political implications of the festival. I will therefore look at a more recent film training and production centre, the Yennenga Centre, founded by another 'rooted cosmopolitan', the transnational FrancoSenegalese filmmaker, Alain Gomis, in order to suggest a link between Ciné Banlieue and the Yennenga Centre. By no means do I wish to imply that all film culture in Senegal is due to Ciné Banlieue and its film festival. Rather, my aim is to show how such an apparently small film festival can greatly contribute to the cultural realm of the country, over time, beyond its festival dates, building on Harbord's understanding of festivals as structures (2016, 70).

As Dina Iordanova notes, "the study of film festivals... encompasses not only the study of the films screened, but also a host of other disciplinary approaches that keep the public sphere in focus" (2016, xiii). One such discipline is cultural policy. The political implications of the BFF have been two-fold. On the one hand, it has represented a project through which political initiatives can support Senegalese film production, both for filmmakers in the country and for the diaspora. On the other hand, it has encouraged the government to reinforce their support for film, and creative industries in Senegal, more broadly. Since the early 2000s, the Senegalese state has been implementing certain cultural policies and initiatives to support cinema, notably through the creation of the DCI and FOPICA. Directed by Hugues Diaz, the DCI aims to promote and develop cinematographic and audiovisual activities in Senegal, through training activities, technical support, as well as the collection and archiving of cinematographic and audiovisual heritage. However, a large number of film festivals have been running without the DCI's financial support, instead relying on fundraising from diverse international institutional sources, and 
less significantly, from private sources. In fact, as stated above, Ciné Banlieue has been running thanks to the generosity of Abdel Aziz Boye and, since his passing, thanks to his disciples, now filmmakers at early stages in their careers. The fourth edition of the BFF, however, was hosted in partnership with DCI, thus benefitting from DCI's platform dedicated to news about film, which includes information about the various film festivals in Senegal, putting them on the map of international film festivals. This gives them visibility, reinforces their establishment as structures and confirms their status as important sites of passage for Senegalese (and international) filmmakers. The partnership with BFF has contributed to the cultural legitimisation of the festival and, therefore, to its growth locally, nationally and internationally.

The most tangible form of state support is the FOPICA, whose executive committee Abdel Aziz Boye joined and where he served as a mediator and gatekeeper. This was a strategic choice: on the one hand, he was able to give young filmmakers access to this funding source; on the other, he allowed the government to reach the emerging filmmakers from the ground. It was the norm to find FOPICA flyers on the desks of Ciné Banlieue, particularly during the 2015 festival, attended by a high number of young cinephiles. Following the international success of Alain Gomis's Félicité (2017), partially funded through FOPICA, the President of Senegal, Macky Sall, doubled the funding. Two years later, Gomis, also a "rooted cosmopolitan" (Sendra 2018), would make his own contribution to Senegal, by establishing , with Aissatou Diop, the Yennenga Centre, a filmmaking hub devoted to training early-career Senegalese filmmakers. ${ }^{13}$ This fledgling yet promising training centre runs practical filmmaking workshops "to accompany young people, some of whom already have some training in their fields, instead of starting a school... and, when necessary, to supplement their knowledge in order to help them become professionals" (Gomis cit. in Barlet 2020). Gomis describes this as a "learning by doing experience" (cit. in Barlet 2020). Aware of the difficulty in accessing the industry for young filmmakers without experiences of international mobility, the practical mentorship by Alain Gomis seeks to offer another entry route to the circuit. On 21 February 2019, Alain Gomis proudly announced the centre debut: "The Yennenga Centre is running! That's it. We exist. We are under construction but we have already started our activities. And we are very happy to present in

${ }^{13}$ This has attracted around 4,000 followers on Facebook in one year, and produced five films and a co-production of a multi-award-winning film internationally, La Nuit des Rois/ Night of the Kings, by Philippe Lacôte (2020). 
FESPACO four of our five first films from the workshop, made in Dakar, with the collaboration of ÉCAL/HEAD" (Gomis 2019). ${ }^{14}$

During April and May 2020, as the world was facing the global pandemic of COVID-19, the Yennenga Centre became one of the first cultural organisations to curate an online film festival programme. On 30 April, a special week hosting a "new wave of African filmmakers" was announced, with the curation of a wide range of titles, some of which made by young filmmakers initially trained at Ciné Banlieue, such as Ordur, by Momar Talla Kandji. Although the Yennenga Centre is a separate initiative, it is worth noting that Alain Gomis's inspiration was directly linked to Ciné Banlieue. In an interview with Olivier Barlet, Gomis confirmed that some of the people they supported were already members of Ciné Banlieue (Barlet, 2020). In fact, Boye's sudden death threatened the third edition of the BFF, due to be hosted a month later. Alain Gomis then became the patron of the festival, at a time when he was already enjoying a position of privilege at international and African film festivals worldwide. This not only secured the continuity of the festival, but also increased the visibility of the project, which was presented as a tribute to Boye. On 14 October 2020, the Yennenga Centre announced the appointment of Oumou Diegane Niange, a young woman filmmaker attached to Ciné Banlieue, as its communications officer. Further analysis of the Yennenga Centre is needed to continue examining the role individual grassroots initiatives like this play in the production and promotion of Senegalese cinema.

\section{Conclusion}

This article sought to fill a significant research gap in the study of film festivals within the context of Senegal. Through the case study of the BFF, I have examined the crucial role of "rooted cosmopolitans" (Appiah 2004) in film festivals, and the festivalisation of Senegal more broadly, within different art and cultural forms. Abdel Aziz Boye is an illustrative example of the role individual grassroots initiatives play in forging the path for actors within the creative industries, in Senegal, and in maintaining the historic role of Senegal in African and global cinema. It is not a surprise that

\footnotetext{
${ }^{14}$ ÉCAL/HEAD is a school based in Dakar, offering a MA in Film Studies. Fifteen of its students were appointed to shoot, in 21 days, five films and two sound creations. These included: Tony (Mamyto Nakamura), Timis (Sarah Rathgeb \& Ketsia Stocker), Clando Bi (Olivia Frey, Elisa Gómez Álvarez, Paul Choquet, Moustapha Guèye and Yoro Mbaye) and Arena (Khadyja Mahfou Aidara, Alarba Bousso, Malou Briand, Oumy Sarr Ndoye, Raphaël Meyer and Mamadou Sané), with a majority of women directors involved.
} 
when the government of Senegal implemented FOPICA, twelve years after the creation of this state cultural policy, Boye was part of the executive committee. In examining the way in which the BFF has contributed to growing cinephilia and the appearance of a new generation of filmmakers in the country, I have explored the legacy of the festival. I have focused on the continuity and growth of the project, both through Ciné Banlieue and the BFF, which are increasingly establishing relations with other film festivals and with the new film training centre, Yennenga, led by another 'rooted cosmopolitan', Alain Gomis. These film organisations have had two main political implications: firstly, they have provided the government with a visible platform for the practical application of their cultural policies, such as FOPICA; secondly, they have encouraged the government to enhance its support of film and screen media production.

In this article, I have also referred to some of the recurrent themes of the films made by Ciné Banlieue members, who have drawn on their own environments, social and cultural concerns, in line with pioneering filmmakers such as Djibril Diop Mambéty, Ousmane Sembène and Safi Faye, who sought to decolonise the cinematic gaze. However, the focus on the transformation of the festival into a structure with long-term impact has not allowed a close analysis of the curatorial aspects of the BFF. Further studies may wish to build on these initial reflections to examine the curated film programmes within different festivals, the trajectories and aesthetic approaches of specific filmmakers and the establishment of online television and production companies, such as Obelus TV, which is currently making films and running film events involving Ciné Banlieue members, all available online. Ultimately, I hope this article fosters future avenues of research within the field of film festivals in Senegal, where festivals are considered as multifaceted structures, collectively and collaboratively shaping the history of cinema in the country.

\section{References}

Andrade-Watkins, Claire. 1993. "Film Production in Francophone Africa." In Ousmane Sembène: Dialogues with Critics and Writers, edited by Samba Gadjigo, Ralph H. Faulkingham, Thomas Cassirer, and Reinhard Sander, 29-36. Amherst: University of Massachusetts Press.

Appiah, Kwame Anthony. 2005. The Ethics of Identity. Princeton, N. J.; Oxford: Princeton University Press. 
2006. Cosmopolitanism: Ethics in a World of Strangers. London: Penguin Books.

Au Sénégal. 2020. "Festival international du film documentaire: appel à films." In Au Sénégal. Last modified April, 29, 2020. Accessed July 7, 2020. https://www.au-senegal.com/festival-international-du-filmdocumentaire-de-saint-louis-appel-a-films,15903.html?lang=fr

Barlet, Olivier, and Chloe Farrell. 2020. "Privileging Other Writings: Interview with Alain Gomis at the Carthage Film Festival." In Black Camera 11 (2): 216-221.

Bisschoff, Lizelle, and Stephanie van de Peer. 2019. Women in African Cinema: Beyond the Body Politic. London: Routledge.

Dakar Ciné. 2019. "Ciné Banlieue: des origines jusqu'au Banlieue Films Festival." Dakar Ciné, 5 December 2019. Accessed 5 November 2020. https://youtu.be/LxrGiq82WW0?fbclid=IwAR2kkux8FuiBhY2mSGX p6Aw1BBo1CiCjBoo0QK1gwrx0x_6VaXP9FK2QmqY

Davies, Amanda. 2011. "Local Leadership and Rural Renewal through Festival Fun: The Case of SnowFest." In Festival Places: Revitalising Rural Australia, edited by Christopher Gibson, and John Connell, 6173. Clevedon: Channel View Publications.

De Valck, Marijke. 2007. Film Festivals: From European Geopolitics to Global Cinephilia. Amsterdam: Amsterdam University Press.

De Valck, Marijke, and Mimi Soetman. 2010. "And the winner is... What happens behind the scenes of film festivals competitions." In International Journal of Cultural Studies 13 (3): 290-307.

De Valck, Marijke, Loist, Skadi, and Kredell, Brendan. 2016. Film Festivals: History, Theory, Method \& Practice. London: Routledge.

Diawara, Manthia. 2000. "The Iconography of West African Cinema." In Symbolic Narratives/African Cinema, edited by June Givanni, 81-89. London: BFI.

2010. African Film: New Forms of Aesthetics and Politics. Munich; London: Prestel.

Diop, Mag Maguette. 2017. Cinéma Sénégalais: Sembène Ousmane. Le Précurseur et son Legs. Dakar : L'Harmattan.

Docmonde. n.d. "The Africadoc Program." Docmonde. Last modified n.d. Accessed July 10, 2020. http://www.docmonde.org/africadoc/ 
Dovey, Lindiwe. 2015. "African Film Festivals in Africa: Curating 'African Audiences' for 'African Films'." In Curating Africa in the Age of Film Festivals, 87-109. New York, NY: Palgrave Macmillan.

Dovey, Lindiwe, McNamara, Joshua and Olivieri, Federico. 2013. "From, by, for: Nairobi's Slum Film Festival, film festival studies, and the practices of development." Jump Cut 55. Accessed 13 July 2020.

http://ejumpcut.org/archive/jc55.2013/DoveySFFNairobi/index.html

Drame, Marième Fatou. 2019. “Cinema: 'Ganja', premier film d'animation sénégalais en 3D.' In Le Soleil, 30 July 2019. Accessed 5 November 2020. http://lesoleil.sn/cinema-ganja-premier-film-danimationsenegalais-en-

3d/?fbclid=IwAR0WqHiC2HZmAyDFxe9lQG511oT9f_EZkJIvTVF2DI pDjV9g7LnEVV810qw

Fléchet, Anaïs, Goetschel, Pascale, Hidiroglou, Patricia, Jacotot, Sophie, Moine, Caroline, Verlaine, Julie (eds). 2013. Une Histoire des Festivals: XX-XXI siècle. Paris: Publications de la Sorbonne.

Harbord, Janet. 2016. "Contingency, time and event: an archaeological approach to the film festival." In Film Festivals: History, Theory, Method, Practice, edited by Marijke de Valck, Brendan Kredell, and Skadi Loist, 69-82. London and New York: Routledge.

Iordanova, Dina. 2016. "Foreword: the film festival and film culture's transnational essence." In Film Festivals: History, Theory, Method \& Practice, edited by Marijke de Valck, Brendan Kredell, and Skadi Loist, xii-xvii. London: Routledge.

Kirshenblatt-Gimblett, Barbara. 1998. Destination Culture: Tourism, Museums and Heritage. Berkeley; London: University of California Press.

Krueger Enz, Molly, and Bryson, Devin (eds). 2018. "Introduction: Forging a New Path: Plurality, Social Change, and Innovation in Contemporary Senegalese Cinema." Black Camera: An International Film Journal 9 (2): 333-348.

Lichaa, Flora. 2017. "A Community at the Margins: An Ethnography of Chinese Independent Film Festivals." In Film Festivals and Anthropology, edited by Aida Vallejo, and María Paz Peirano, 293304. Newcastle upon Tyne, England: Cambridge Scholars Publishing.

Loist, Skadi. 2016. "The film festival circuit: networks, hierarchies, and circulation." In Film Festivals: History, Theory, Method \& Practice, 
edited by Marijke de Valck, Brendan Kredell, and Skadi Loist, 49-64. London: Routledge.

Mano, Winston, Knorpp, Barbara, and Agina, Añulika. 2017. African Film Cultures: Context of Creation and Circulation. Newcastle upon Tyne, UK: Cambridge Scholars Publishing.

Neveu Kringelbach, Hélène. 2013. Dance Circles: Movements, Morality and Self-fashioning in Urban Senegal. New York: Berghahn Books.

Pfaff, Françoise. 1984. The Cinema of Ousmane Sembène, a Pioneer of African Film. Westport: Greenwood Press.

Peirano, María Paz. 2017. "Ethnographic and Indigenous Film Festivals in Latin America: Constructing Networks of Film Circulation." In Film Festivals and Anthropology, edited by Aida Vallejo, and María Paz Peirano, 77-88. Newcastle upon Tyne, England: Cambridge Scholars Publishing.

Quinn, Bernadette and Linda Wilks. 2016. "Linking Social Capital, Cultural Capital and Heterotopia at the Folk Festival." Journal of Comparative Research in Anthropology and Sociology 7 (1): 23-39.

Le Quotidien. 2018. “Cinéma : Les Recidak reviennent en novembre.” Le Quotidien. Last modified October 20, 2018. Accessed 7 July, 2020. https://www.lequotidien.sn/cinema-les-recidak-reviennent-ennovembre/

Sendra, Estrella. 2017a. "Luto en el cine senegalés tras la muerte de Abdel Aziz Boye." Wiriko. Last modified November 14, 2017. https://www.wiriko.org/cine-audiovisuales/luto-cine-senegalesabdel-aziz-boye/

2017b. "Le cinéaste et formateur Abdel Aziz Boye décédé jeudi." Le Soleil. Last modified November 12, 2017: 13. Accessed July 10, 2020. https://en.calameo.com/read/000275347792e6128c745

. 2018. "Displacement and the Quest for Identity in Alain Gomis's Cinema." Black Camera: An International Film Journal 9 (2): 360-390. https://www.jstor.org/stable/10.2979/blackcamera.9.2.23?seq=1

Sencinema. n.d. "SENCINEMA: Le portail du Cinéma Sénégalais." Accessed July 14, 2020. http://www.sencinema.org

Ukadike, Nwachukwu Frank. 2002. Questioning African Cinema: Conversations With Filmmakers. Minneapolis: University of Minnesota Press. 


\section{Filmography}

Arena. Dir. Khadyja Mahfou Aidara, Alarba Bousso, Malou Briand, Oumy Sarr Ndoye, Raphaël Meyer and Mamadou Sané. Senegal, 2018. 13 minutes.

Atlantique / Atlantics. Dir. Mati Diop. Senegal-France, 2019. 107 minutes.

Baye Fall, Le Soldat de la Paix/ Baye Fall, Peace Soldiers. Dir. Pape Bole Thiaw. Senegal, 2015. 13 minutes. Available online (8 November 2020). https://vimeo.com/157922056

Borom Sarret. Dir. Ousmane Sembène. Senegal, 1963. 22 minutes.

Clando Bi. Dir. Olivia Frey, Elisa Gómez Álvarez, Paul Choquet, Moustapha Guèye and Yoro Mbaye. Senegal, 2018, 17 minutes.

Contras' City / City of Contrasts. Dir. Djibril Diop Mambéty. Senegal, 1969. 22 minutes.

Daani Doolé/ Self-autonomy. Dir. Pape Bolé thiaw. Senegal, 2017. 13 minutes.

Félicité. Dir. Alain Gomis. Senegal-France-Belgium-Germmany-LebanonThe Democratic Republic of Congo, 2017. 129 minutes.

Fresque Francophone. Dir. Ousmane William Mbaye. Senegal, 1992. 13 minutes.

Ganja. Dir. Amath Ndiaye. Senegal, 2019. 10 minutes.

Gueti Goudi. Dir. Amath Ndiaye. Senegal, 2012. 6 minutes. Available online $(24$ March 2018). https://www.youtube.com/watch?v=xCB7bj2JEOo

Guinaw Rails / Behind the Rails. Dir. Kady Diedhiou. Senegal, 2014. 13 minutes.

Et la Neige n'Était Plus. Dir. Ababacar Samb Makharam. Senegal, 1965. 21 minutes. Available online (23 January 2017). https://www.youtube.com/watch?v=beQhdRv0ANE

La Noire De... / Black Girl. Dir. Ousmane Sembène. Senegal, 1966. 80 minn.

Kaddu Beykat / Letter from the Village. Dir. Safi Faye. Senegal, 1975. 90 minutes.

Linguère. Dir. Momar Talla Kandji et al. Senegal, 2015. 26 minutes.

Mossane. Dir. Safi Faye. Senegal, 1996. 105 minutes.

Muruna. Dir. Moly Kane. Senegal, 2015. 15 minutes. 
Niaka. Dir. Baba Diedhou. Senegal, 2019. 17 minutes.

La Nuit des Rois/Night of the Kings. Dir. Philippe Lacôte. France, Ivory Coast, Canada, Senegal, 2020. 93 minutes.

Ordur / Trash. Dir. Momar Talla Kandji. Senegal, 2018. 15 minutes.

Tey / Today. Dir. Alain Gomis. Senegal-France, 2012. 86 minutes.

Timis. Dir. Sarah Rathgeb \& Ketsia Stocker, Senegal, 2019, 20 minutes.

Tony. Dir. Mamyto Nakamura. Senegal, 2018. 21 minutes.

Touki Bouki / Journey of the Hyena. Djibril Diop Mambéty. Senegal, 1973. 95 minutes.

Une Place Dans l'Avion / A Seat on the Plane. Khadidiatou Sow. Senegal, 2016. 16 minutes.

Une Simple Parole. Dir. Khady and Mariama Sylla. Senegal, 2014. 63 minutes.

\section{Interviews}

Cissé, Nazir. 2017. Personal communication (Facebook interview). Ciné Banlieue. November 10.

Danso, Keba. 2017. Personal communication (telephone interview). Ciné Banlieue. November 10.

Olivieri, Federico. 2016. Personal communication (email interview). Banlieue Films Festival. January 2.

Thiaw, Pape Bolé. 2015 \& 2017. Personal communication (audio recorded interview and phone interview). Banlieue Films Festival. December 12, 2015, November 10, 2017.

\section{Banlieue Films Festival (BFF): A nova cinefilia e a produção de filmes no Senegal}

RESUMO Este artigo examina pequenos festivais de cinema no contexto sociocultural do Senegal. Através do estudo de caso do Banlieue Films Festival (BFF) de Dakar, fundado em 2013 por Abdel Aziz Boye, analiso o papel crucial dos festivais no fortalecimento da indústria cinematográfica, fomentando a cinefilia e incentivando a aplicação prática das políticas culturais. Sugiro que a produção cinematográfica contemporânea, particularmente nos últimos cinco anos (2015-2020), foi significativamente moldada por iniciativas de base que acabaram se transformando em estruturas. Também exploro o papel dos "cosmopolitas enraizados", tomando emprestado o termo de Kwame Appiah em 
relação à figura de Abdel Aziz Boye, que fundou o Ciné UCAD na Université Cheikh Anta Diop, em Dakar, Ciné Banlieue, e, ao retornar ao Senegal vindo da França, o BFF. Discuto as várias formas de legado de BFF, concluindo que tem sido um agente ativo na formação de uma nova cinefilia e inspirador de uma onda de jovens cineastas no Senegal.

PALAVRAS-CHAVE Banlieue Films Festival; produção de cinema senegalense; cinefilia; "cosmopolita enraizado"; etnografia.

Recebido a 11-07-2020. Aceite para publicação a 8-12-2020. 